\title{
Avoidable causes on the waiting list for admissions to intensive care units
}

\author{
Causas evitáveis na lista de espera para internação em unidades de terapia intensiva
}

Guido Luis Gomes Otto ${ }^{1}$, Marielle Priscila de Paula Silva ${ }^{1}$, Cássia Kely Favoreto Costa ${ }^{1}$, Marcelo Picinin Bernuci ${ }^{1}$, Mirian Ueda Yamaguchi ${ }^{1}$

Objective: to evaluate occurrence of avoidable-mortality causes on the waiting list of patients at the intensive care units. Methods: one thousand, two hundred and twelve enrollments of patients from all age groups were analyzed and classified according to the Brazilian Health System for causes of avoidable mortality. Descriptive statistics for simple, relative and mean frequency rates were employed for the comparative analysis of the variables. Results: cases of non-communicable diseases, among the avoidable-mortality causes, occupied more than $80.0 \%$ of intensive care unit's beds. Hospitalizations comprised illnesses of the circulatory and respiratory apparatus, especially in patients over 40 years old, together with the external causes and consequences of pregnancy and puerperium with mortality rates within the 15-39 age group. Conclusion: the high proportion of patients with diseases from avoidable causes on the waiting list for intensive care units hospitalization suggest that improvements in the programs involved with the prevention of diseases, especially non-communicable diseases, are needed.

Descriptors: Mortality; Chronic Disease; Unified Health System.

Objetivo: avaliar a ocorrência de causas de mortalidade evitáveis na lista de espera de pacientes nas unidades de terapia intensiva. Métodos: mil e duzentas e doze inscrições de pacientes de todas as faixas etárias foram analisadas e classificadas de acordo com o Sistema Único de Saúde para as causas de mortalidade evitável. Estatística descritiva para taxas de frequência simples, relativas e médias foi empregada para a análise comparativa das variáveis. Resultados: casos de doenças não transmissíveis, entre as causas evitáveis de mortalidade, ocupavam mais de 80,0\% de leitos da unidade de terapia intensiva. Internações incluíam doenças dos aparelhos circulatório e respiratório, especialmente em pacientes com mais de 40 anos de idade, juntamente com causas externas e as consequências da gravidez e puerpério, com taxas de mortalidade no grupo de 1539 anos. Conclusão: a alta proporção de pacientes com doenças de causas evitáveis na lista de espera para internação em unidades de terapia intensiva sugere que são necessárias melhorias nos programas relacionados à prevenção de doenças, principalmente de doenças não transmissíveis.

Descritores: Mortalidade; Doença Crônica; Sistema Único de Saúde.

${ }^{1}$ Centro Universitário de Maringá. Maringá, PR, Brazil.

Corresponding author: Mirian Ueda Yamaguchi

Centro Universitário de Maringá. Av Guedner, 1610, CEP: 87050-900. Maringá, PR, Brazil. E-mail: mirian.yamaguchi@unicesumar.edu.br 


\section{Introduction}

The Brazilian Health System was established in Brazil in 1988, and health was proclaimed as a citizen's right and the duty of the State. After more than two decades, the Brazilian Health System has promoted significant improvements in public health, even though important challenges have still to be met. Brazil, significantly reduced its infant mortality rates (from 69/1000 to 14/1000) between 1980 and $2013^{(1)}$, together with an increase in the mean life expectancy of the population (from 62.6 to 75.5 years) (2). $^{(2)}$

Brazil ranks $85^{\text {th }}$ in the Human Development Index (0.730), although extreme differences in Brazilian towns and regions occur in this developing continent-size country. Whereas the city of São Caetano do Sul in the state of São Paulo features the highest Human Development Index score (0.860) in Brazil, the town of Melgaço in the northern state of Pará has an Human Development Index of 0.418. The present analysis was undertaken in the macro-region of Maringá, with an estimated population of 1,719,682 inhabitants $(2010)^{(3)}$, in the southern state of Paraná (Human Development Index $=0.749$ ). The city of Maringá has an Human Development Index $=0.808$, i.e., it ranks $23^{\text {rd }}$ in Brazil and $46^{\text {th }}$ in world ranking.

The demand for intensive-care therapy in Brazil is high and costs are rapidly increasing. The high costs are mainly due to the advanced technology and specialized human resources required for this type of care ${ }^{(4)}$. The intensive care units are equipped with ventilators, hemodialysis machines, extracorporeal circulation apparatus, and others ${ }^{(5-6)}$. The costs are paid by the Brazilian Health System, by private health plans, or by the patients and their relatives.

To guarantee total access to health services, the Brazilian Health System organizes assistance regulation centers by subjects or assistance areas, such as obstetrics and neonatal, urgent and emergency care, high complexity, transplants, hospitalization and others. The centers link the existing demand with available resources, so that the best assistance response can be provided equally to all, with good quality and at the appropriate time. In the wake of an increase in the demand for health services by the Brazilian population, an analysis of the occurrence of illnesses related to causes of avoidable mortality seems useful. Causes of avoidable mortality are illnesses which may be prevented by certain healthpromoting activities, and which play an important role in combating these causes ${ }^{(7)}$.

The present investigation analyzed the occurrence of avoidable-mortality causes on the waiting list of patients at the Intensive Care Unit Bed Regulation Center in the region of Maringá, state of Paraná, Brazil. This survey will provide data for studies on disease prevention and health promotion activities that would minimize demands for hospital bed space by diverting human, financial and social resources to other health sectors and providing better service to the population.

\section{Methods}

This study is a descriptive, retrospective and exploratory analysis, featuring secondary data collection on patients enrolled on the intensive care units waiting list of the health macro-region of Maringá between July and December 2012. Information on 1212 solicitation records for Intensive Care Unit hospitalization was available from the data base of the Hospital Bed Center of the $15^{\text {th }}$ Regional Health Unit of Maringá, and was retrieved by permission.

The variables analyzed comprised: a) patient's gender, b) age, c) diagnosis classified according to the International Classification of Diseases 10, and d) causes of avoidable and non-avoidable mortality. For data analysis we used the distribution of simple and relative frequency, average calculation and standard deviation and $\mathrm{Z}$ statistical test, which is used to test the null hypothesis that there is no difference between the means of two populations against alternative 
hypothesis that exist differences between them ${ }^{(8)}$. The level of significance was $5 \%$.

Patients from all age groups and resident in the macro-region of Maringá were included in the study. Avoidable causes, identified as those cases which could be avoided by prevention and health promotion, were classified according to the list of avoidable causes of death by the Brazilian Health System $^{(9)}$ described as those reducible by: immunoprevention measures; appropriate measures for health promotion, prevention, control and care of infectious diseases; appropriate measures for health promotion, prevention, control and care of non-communicable diseases; appropriate measures for health promotion, prevention, control and care of external causes.

The records regarding the waiting list of patients at the intensive care units were identified according to the International Diseases Classification as previously described. Only those records included in the list of preventable causes of death adopted by Health Unit System were selected for the study ${ }^{(9)}$.

The study complied with the formal requirements contained in the national and international regulatory standards for research involving human beings.

\section{Results}

Of 1212 patients, $50.4 \%$ were males, between 0 and 97 years (mean age 51.3 years). The $60-79$ and 40-59 age groups showed the highest rates of demand for intensive care unit beds. The 15-19 age group had the lowest intensive care units demand (Table 1). Non-avoidable causes were significant within the 0-14 and 20-39 age groups, whereas the 60-79 age group had the highest rates of avoidable mortality-causing diseases (Table 1).
Table 1 - Reports of intensive care unit hospitalization demand by gender and age comparing avoidable and non-avoidable mortality causes

\begin{tabular}{lcccc}
\hline & \multicolumn{4}{c}{ Type of cause } \\
\cline { 2 - 5 } Profile & $\begin{array}{c}\text { Avoidable Non-avoidable } \\
\mathbf{n ~ ( \% )}\end{array}$ & $\mathbf{p}(\%)$ & $\begin{array}{c}\text { Total } \\
\mathbf{n}(\%)\end{array}$ \\
\hline Gender & & & & \\
Male & $539(54.6)$ & $72(32.1)$ & $<0.05^{*}$ & $611(50.4)$ \\
Female & $449(45.4)$ & $152(67.9)$ & $<0.05^{*}$ & $601(49.6)$ \\
Age group (years) & & & & \\
$0-14$ & $50(5.1)$ & $66(29.5)$ & $<0.005^{*}$ & $116(9.5)$ \\
$15-19$ & $31(3.1)$ & $24(10.7)$ & 0.2377 & $55(4.5)$ \\
$20-39$ & $148(15.0)$ & $60(26.8)$ & $<0.05^{*}$ & $208(17.1)$ \\
$40-59$ & $252(25.5)$ & $21(9.4)$ & 0.0838 & $273(22.5)$ \\
$60-79$ & $367(37.1)$ & $41(18.3)$ & $0.05^{*}$ & $408(33.6)$ \\
$>80$ & $140(14.2)$ & $12(5.4)$ & 0.3795 & $152(12.5)$ \\
Total & $988(100.0)$ & $224(100.0)$ & & $1212(100.0)$ \\
*Significant Z Test $<5 \%$ & & &
\end{tabular}

The classification of patients who were ill from avoidable causes and needed intensive care unit beds showed that $69 \%$ suffered from non-communicable diseases, followed by infectious diseases and external causes (Table 2).

Table 2 - Classification and occurrence of avoidable causes in intensive care units hospitalization requests, and mean age in years

\begin{tabular}{lcc}
\hline Classification & n (\%) & Age (DP) \\
\hline Communicable diseases & $53(5.0)$ & $48.7(31.6)$ \\
Infectious diseases & $130(13.0)$ & $61.8(22.9)$ \\
Non-communicable diseases & $678(69.0)$ & $58.4(20.4)$ \\
External causes & $127(13.0)$ & $37.9(22.7)$ \\
Total & $988(100.0)$ & \\
\hline
\end{tabular}

As seen in Table 3, diseases of the circulatory system accounted for $43.6 \%$ of overall intensive care units bed requests, followed by respiratory diseases $(12.9 \%)$ and by diseases during pregnancy, birth and puerperium (11.4\%). Avoidable causes totaled $82 \%$, with diseases of the circulatory system comprising $50.3 \%$ of this category, followed by respiratory diseases $(14.6 \%)$ and external causes $(12.2 \%)$. 
Table 3 - Intensive care units hospitalization requests classified as avoidable and non-avoidable causes, distributed according to the International Classification of Diseases

\begin{tabular}{|c|c|c|c|}
\hline \multirow[b]{2}{*}{ International Diseases Classification } & \multicolumn{3}{|c|}{ Type of cause } \\
\hline & $\begin{array}{c}\text { Non-avoidable } \\
\text { n (\%) }\end{array}$ & $\begin{array}{c}\text { Avoidable } \\
\text { n (\%) } \\
\end{array}$ & $\begin{array}{c}\text { Overall } \\
\text { n (\%) }\end{array}$ \\
\hline Diseases of the circulatory system & $32(14.3)$ & $497(50.3)$ & $529(43.6)$ \\
\hline Respiratory diseases & $12(5.4)$ & $144(14.6)$ & $156(12.9)$ \\
\hline Pregnancy, birth, puerperium & $72(32.1)$ & $66(6.7)$ & $138(11.4)$ \\
\hline External causes & - & $120(12.2)$ & $120(9.9)$ \\
\hline Infectious and parasite diseases & $4(1.8)$ & $72(7.3)$ & $76(6.3)$ \\
\hline Diseases of the digestive system & $20(8.9)$ & $29(2.9)$ & $49(4.0)$ \\
\hline Illnesses during perinatal period & $33(14.7)$ & - & $33(2.7)$ \\
\hline Diseases of the genito-urinary apparatus & $5(2.2)$ & $26(2.6)$ & $31(2.6)$ \\
\hline Diseases of the Nervous System & $7(3.1)$ & $11(1.1)$ & $18(1.5)$ \\
\hline Congenital malformations & $17(7.6)$ & - & $17(1.4)$ \\
\hline Abnormal signs and symptoms & $9(4.0)$ & $7(0.7)$ & $16(1.3)$ \\
\hline Endocrinal diseases & $1(0.4)$ & $8(0.8)$ & $9(0.7)$ \\
\hline Cancers & $7(3.1)$ & $1(0.1)$ & $8(0.7)$ \\
\hline Factors that affect health conditions & - & $6(0.6)$ & $6(0.5)$ \\
\hline Blood diseases & $5(2.2)$ & $1(0.1)$ & $6(0.5)$ \\
\hline Total & $224(100.0)$ & $988(100.0)$ & $1212(100.0)$ \\
\hline
\end{tabular}

Table 4 - Avoidable causes and classification according to International Classification of Diseases by age group

\begin{tabular}{|c|c|c|c|c|c|c|c|}
\hline \multirow[b]{2}{*}{ Intensive Care Unit } & \multicolumn{7}{|c|}{ Age group } \\
\hline & $\begin{array}{c}0-14 \\
\text { n (\%) }\end{array}$ & $\begin{array}{l}15-19 \\
n(\%)\end{array}$ & $\begin{array}{l}20-39 \\
\text { n (\%) }\end{array}$ & $\begin{array}{l}40-59 \\
\text { n (\%) }\end{array}$ & $\begin{array}{l}60-79 \\
\text { n (\%) }\end{array}$ & $\begin{array}{c}>80 \\
\text { n (\%) }\end{array}$ & $\begin{array}{l}\text { Total } \\
\text { n (\%) }\end{array}$ \\
\hline Respiratory diseases & $23(46.0)$ & $1(3.0)$ & $10(7.0)$ & $16(6.0)$ & $66(18.0)$ & $28(20.0)$ & $144(14.6)$ \\
\hline External causes & $14(28.0)$ & $12(39.0)$ & $45(30.0)$ & $28(11.0)$ & $18(5.0)$ & $3(2.0)$ & $120(12.1)$ \\
\hline Diseases of the digestive system & $1(2.0)$ & - & $4(3.0)$ & $17(6.9)$ & $5(1.0)$ & $2(1.0)$ & $29(2.9)$ \\
\hline Diseases of the circulatory system & $2(4.0)$ & - & $29(20.0)$ & $157(62.0)$ & $224(61.0)$ & $85(61.0)$ & $497(50.3)$ \\
\hline Endocrine diseases & $3(6.0)$ & $1(3.0)$ & - & - & $3(1.0)$ & $1(1.0)$ & $8(0.8)$ \\
\hline Diseases of genito-urinary system & - & $1(3.0)$ & - & $7(3.0)$ & $14(4.0)$ & $4(3.0)$ & $26(2.6)$ \\
\hline Pregnancy, birth or postpartum & $2(4.0)$ & $12(39.0)$ & $48(32.0)$ & $4(2.0)$ & - & - & $66(6.7)$ \\
\hline Diseases of the nervous system & $3(6.0)$ & $1(3.0)$ & $2(1.0)$ & $4(2.0)$ & - & $1(1.0)$ & $11(1.1)$ \\
\hline Abnormal signs and symptoms & - & $1(3.0)$ & $1(1.0)$ & $1(0.4)$ & $1(0.4)$ & $3(2.0)$ & $7(0.7)$ \\
\hline Factors that affect health conditions & - & - & $3(2.0)$ & $1(0.4)$ & - & $2(1.0)$ & $6(0.6)$ \\
\hline Infectious and parasitic diseases & $2(4.0)$ & $1(3.0)$ & $6(4.0)$ & $16(6.0)$ & $36(10.0)$ & $11(8.0)$ & $72(7.3)$ \\
\hline Cancers & - & - & - & $1(0.4)$ & - & - & $1(0.1)$ \\
\hline Blood diseases & - & $1(3.0)$ & - & - & - & - & $1(0.1)$ \\
\hline Total & $50(100.0)$ & $31(100.0)$ & $148(100.0)$ & $252(100.0)$ & $367(100.0)$ & $140(100.0)$ & $988(100.0)$ \\
\hline
\end{tabular}


Taking age groups into consideration, avoidable causes of mortality within the $0-14$ age group comprised primarily respiratory diseases, followed by external causes; within the 15-19 age group, external causes amounted to $39.0 \%$, followed by causes during pregnancy, birth and puerperium, with equal percentages. External causes amounted to $30.0 \%$ for the $20-39$ age group and $32.0 \%$ for causes related to pregnancy and diseases of the postpartum period. Diseases of the circulatory system accounted for $62.0 \%$ of the intensive care unit bed requests for the $40-59$ age group, and $61.0 \%$ in the $60-79$ and over-80 groups. Respiratory diseases comprised 18 and $20.0 \%$ of the requests respectively within the last two groups (Table 4).

\section{Discussion}

Quality and efficient care in medicine require accurate diagnosis of the patients' illnesses. The main challenges to improving the health of a population, with its continuing changes, must be understood, so that health systems can provide efficacious care. The financial resources for health are never adequate and perhaps never will be. This is due to growing demands that accompany an aging population and changes in the profile of illnesses, especially non-communicable ones. New technologies are added to old ones, which are never replaced and together increase health costs. When financial resources for the health sector are insufficient, the best strategy is not to save money but to apply the available resources in the best possible way $^{(10)}$. Consequently, emphasis on decreasing the demand caused by avoidable diseases and reducing hospitalization costs is mandatory. This process would be an asset in the application of resources with regard to improvement of treatments, and in improving understanding of diseases in general.

Intensive care units are extremely important health tools for the population, which is increasingly aging and, consequently, incurs high costs for care. Prevention of avoidable diseases and the optimization of intensive care units management, featuring a strategic perspective, patient-centered quality, focus on results and continuous learning ${ }^{(4)}$ all have important roles in decreasing costs and maximizing use of the available resources. The National Health System's mean monthly expenses in Maringá during the first quarter of 2010 were about US\$ 1.6 million for 703 hospital beds, including 64 (9.1\%) intensive care unit beds with a mean of 2740 patients per month at a mean cost of US\$ 590.00/patient/month. The daily cost per patient in intensive care units is about US\$285.00 ${ }^{(11)}$.

The present results showed that $82 \%$ of the demand on the waiting list for intensive care unit beds consisted of patients with illnesses from avoidable causes within the 60-79-year age group $(\mathrm{p}<0.05)$. These data concord with the information presented in the 2013 World Health Organization report $^{(12)}$. Avoidable causes occurred significantly more often $(p<0.05)$ in males. This contrasts with report described in the 2011 summary by the PanAmerican Health Organization, which found no significant difference between males and females ${ }^{(13)}$. The cardiovascular diseases comprise the highest share of non-communicable diseases, in agreement with the present results $(69.0 \%)^{(14)}$. Non-avoidable causes were significantly more common in the age groups below 15 years $(\mathrm{p}=0.0014)$ and within the 20 39 age group ( $\mathrm{p}=0.0446)$.

An analysis of intensive care unit demands for cases of diseases from avoidable causes demonstrated that $50.3 \%$ were circulatory diseases and $14.6 \%$ were respiratory ones, i.e., a significant predominance. Several studies have shown that smoking in developing countries is an important risk factor for mortality. In its 2013 Conference, the Word Health Organization suggested an increase in cigarette taxes as a strategy to decrease smoking ${ }^{(15)}$.

Among the diseases with avoidable causes, external causes predominated in patients younger than 40 , whereas in the case of respiratory diseases, patients younger than 15 years predominated. 
Educational efforts to decrease violence in the home and on the roads should be prioritized, since they contribute to the decline of the mortality rate from external causes. The joint efforts of governments and organizations to make accessible efficient vaccines for the prevention of respiratory illnesses have increased, combined with scientific, medical and biotechnological progress which improves current vaccines and contributes toward a future in which respiratory diseases decrease ${ }^{(16)}$.

Diseases related to pregnancy, birth and postpartum complications had the highest occurrences within the 15-39 age group, very similar to that in other regions worldwide. Enormous challenges persist in improving mother-infant health on the planet. In developing countries, maternalinfant health programs are still fragmented and must emphasize essential interventions and working with other programs for specific illnesses ${ }^{(17)}$.

Health prevention and promotion programs for the population below 15 years of age should focus on respiratory diseases and diseases related to external causes. These programs should be continued with people up to 39 years of age, combined with care during pregnancy, birth and postpartum ${ }^{(17)}$. Circulatory diseases occur in more than $60.0 \%$ of the population over 40 years of age, and respiratory diseases combined with circulatory ones reappear in the population over 60 . Health prevention and promotion programs should be intensified to combat diseases of the circulatory system, such as systemic arterial hypertension, and coronary-arterial and vascular-cerebral diseases. Efforts to promote physical activity, healthy eating habits, maintenance of ideal body weight, and anti-smoking and anti-alcohol campaigns should be addressed to the population over 39 years $^{(18)}$.

Life habits are important factors affecting the patterns of risk for non-communicable diseases, and current efforts to decrease smoking, alcohol intake and, more recently, the consumption of trans fats and salt show that there are many health prevention and promotion initiatives to be undertaken. These may include the establishment of public policies, such as increasing the tax on cigarettes and restrictions on alcohol intake. Bold and creative policies are required to combat the excessive consumption of alcohol, improve dietary habits, and increase physical activity ${ }^{(18)}$.

Non-communicable diseases are a major challenge to public health in the 21st century. The prevention of premature deaths from avoidable causes and the resulting decrease in health costs related to these diseases are the main aims of health policies. Improving the detection and treatment of non-communicable diseases and the prevention of complications and catastrophic events are the main aims of clinical medicine. A multidisciplinary approach that integrates policies, regulations, health education, and adequate health systems sufficient to attain these aims is the great mission of public health. All countries are benefited when they share experiences and technical knowledge for the prevention and control of non-communicable diseases ${ }^{(19)}$. Forty years after the extinction of infectious diseases and multi-resistant pathogens was declared, new diseases such as human immunodeficiency virus syndrome, viral SARS and the H1N1 influenza virus have caused pandemics, and old diseases such as tuberculosis and cholera are still extant. Increases in life expectancy and rapid social changes have led to a persistent increase in chronic diseases, for which efficacious therapies exist, but which frequently are not available to or sufficiently efficacious for the most needy population ${ }^{(20)}$.

The results of the present study show that noncommunicable diseases, represented by diseases of the circulatory and respiratory systems, cause more than $80.0 \%$ of the demand for intensive care unit beds in the region of Maringá, especially within the over40 age group. In addition, adolescents fall ill from external causes, and complications of pregnancy and puerperium are highly important factors affecting mortality rates in the 15-39 age group. 


\section{Conclusion}

Despite the intensive efforts for disease prevention and health promotion, the high proportion of patients with diseases from avoidable causes on the waiting list for intensive care units hospitalization indicates the enormous task still to be done and great improvements in the prevention of diseases, especially non-communicable diseases, are mandatory. Current prevention and health-promotion campaigns must be implemented and expanded.

\section{Collaborations}

Otto GLG and Yamaguchi MU contributed to the collection, organization, analysis and interpretation of data and article writing. Silva MPP contributed in the collection and organization of data. Costa CKF and Bernuci MP contributed to the analysis, data interpretation, article writing and final version to be published.

\section{References}

1. United Nations Children's Fund (UNICEF). Committing to child survival: a promise renewed. [Internet] 2014 [cited 2015 Sept. 15]. Available at http://www.unicef.org/philippines/APR2014_ Sep2014.pdf

2. Word Health Organization (WHO). World Health Statistics 2014. [Internet] 2014 [cited 2015 Sept. 15]. Available at http://apps.who.int/iris/ bitstream/10665/112738/1/9789240692671_ eng.pdf

3. Programa das Nações Unidas para o Desenvolvimento (PNUD). Ranking IDH dos municípios. [Internet] 2010 [citado 2015 set 15]. Disponível em: http://www.pnud.org.br/atlas/ ranking/Ranking-IDHM-Municipios-2010.aspx

4. Fernandes HS. Gestão em terapia intensiva: conceitos e inovações. Rev Soc Bras Clin Med. 2011; 9(2):129-37.
5. Gandra S, Ellison RT. Modern trends in infection control practices in intensive care units. J Intensive Care Med. 2014; 29(6):311-26.

6. Hodgson CL, Berney S, Harrold M, Saxena M, Bellomo R. Clinical review: early patient mobilization in the ICU. Crit Care. 2013; 17(1):207.

7. Kanso S, Romero DE, Leite IC, Marques A. Avoidability of deaths from chronic illnesses in elderly individuals in São Paulo, Brazil. Cad Saúde Pública. 2013; 29(4):735-48.

8. Diaz FR, López JB. Bioestatística. São Paulo: Cengage Learning; 2012.

9. Malta DC, Sardinha LMV, Moura L, Lansky S, Leal MC, Szwarcwald CL, et al. Atualização da lista de causas de mortes evitáveis por intervenções do Sistema Único de Saúde do Brasil. Epidemiol Serv Saúde. 2010; 19(2):173-6.

10. Scheunemann LP, White DB. The Ethics and Reality of Rationing in Medicine. Chest. 2011; 140(6):1625-32.

11. Ministério da Saúde (BR). Recursos Federais do SUS por Município. [Internet]. 2012 [citado set 15]. Disponível em: http://www2.datasus.gov.br/ DATASUS/index.php?area $=05$

12. World Health Organization (WHO). Noncommunicable diseases. [Internet] 2013 [cited 2015 Sept. 15]. Available from: http://www.who. $\mathrm{int} / \mathrm{nmh} /$ events/essential_medicines_2jul15_ portugese.pdf.

13. Goulard FAA. Doenças Crônicas não Transmissíveis: estratégias de controle e desafios para os sistemas de saúde [Internet]. 2011 [citado 2015 set 15]. Disponível em: http://apsredes. org/site2012/wp-content/uploads/2012/06/ Condicoes-Cronicas_flavio1.pdf

14. Murray CJ, Vos T, Lozano R, Naghavi M, Flaxman AD, Michaud C, et al. Disability-adjusted life years (DALYs) for 291 diseases and injuries in 21 regions, 1990-2010: a systematic analysis for the Global Burden of Disease Study 2010. Lancet. 2012; 380(9859):2197-223.

15. Jamison DT, Summers LH, Alleyne G, Arrow KJ, Berkley S, Binagwaho A, et al. Global health 2035: a world converging within a generation. Lancet. 2013; 382(9908):1898-955. 
16. Nabel GJ. Designing tomorrow's vaccines. N Engl J Med. 2013; 368(6):551-60.

17. Bhutta AZ, Black RE. Global maternal, newborn, and child health - so near and yet so far. N Engl J Med. 2013; 369(23):2226-35.

18. Ezzat M, Riboli E. Behavioral and dietary risk factors for non-communicable diseases. $\mathrm{N}$ Engl J Med. 2013; 369(10):954-64.
19. Hunter DJ, Reddy KS. Non-communicable diseases. N Engl J Med. 2013; 369(14):1336-43.

20. Farmer PE. Infectious disease and the future of health care delivery. N Engl J Med. 2013; 369(25):2424-36. 